\title{
Assumptions of authority: the story of Sue the T-rex and controversy over access to fossils
}

\author{
Elizabeth D. Jones ${ }^{1,2}$
}

Received: 26 October 2018 / Accepted: 11 October 2019 / Published online: 31 December 2019 (C) The Author(s) 2019

\begin{abstract}
Although the buying, selling, and trading of fossils has been a principle part of paleontological practice over the centuries, the commercial collection of fossils today has re-emerged into a pervasive and lucrative industry. In the United States, the number of commercial companies driving the legal, and sometimes illegal, selling of fossils is estimated to have doubled since the 1980s, and worries from academic paleontologists over this issue has increased accordingly. Indeed, some view the commercialization of fossils as one of the greatest threats to paleontology today. In this article, I address the story of "Sue" - the largest, most complete, and most expensive Tyrannosaurus rex ever excavated-whose discovery incited a series of high-profile legal battles throughout the 1990s over the question of "Who owns Sue?" Over the course of a decade, various stakeholders from academic paleontologists and fossil dealers to Native Americans, private citizens, and government officials all laid claim to Sue. In exploring this case, I argue that assumptions of authority are responsible for initiating and sustaining debates over fossil access. Here, assumptions of authority are understood as assumptions of ownership, or expertise, or in some cases both. Viewing the story from this perspective illuminates the significance of fossils as boundary objects. It also highlights the process of boundarywork by which individuals and groups constructed or deconstructed borders around Sue (specifically) and fossil access (more generally) to establish their own authority. I draw on science studies scholarship as well as literature in the professionalization, commercialization, and valuation of science to examine how assumptions of authority facilitated one of the most divisive episodes in recent paleontological history and
\end{abstract}

Elizabeth D. Jones

elizabeth_jones@ncsu.edu; elizabeth.jones.13@ucl.ac.uk

1 Department of Forestry and Environmental Resources, North Carolina State University, 2820 Faucette Drive Campus, Box 8001, Raleigh, NC 27606, USA

2 Department of Science and Technology Studies, University College London, 22 Gordon Square, London WC1E 6BT, UK 
the broader debate on the commercial collection of vertebrate fossil material in the United Sates.

Keywords Paleontology - Dinosaurs - Professionalization - Commercialization · Valuation · Boundary objects · Boundary-work · Access · Ownership · Expertise

\section{Introduction}

Writing for Science in 1992, journalist Virginia Morell commented on the once open and accepting atmosphere of the Society of Vertebrate Paleontology (SVP)—now the largest international academic organization dedicated to the study of vertebrate paleontology (Morell 1992). According to Morell, one paleontologist and member of the United States Geological Survey, George Edward Lewis, stood by the accessible and inclusive nature of the SVP, reportedly claiming that "any S.O.B. with an interest in old bones" could join. To prove his point, Lewis nominated his dog for membership, and as the story goes, the dog was accepted for election to the society. But that was in the 1960s. And as far as Morell was concerned, times were changing. Indeed, recent events seemed to suggest that some academic paleontologists were becoming less accepting. Some were especially skeptical of prospective members with a commercial interest in fossils. These paleontologists felt threatened by the increasing valuation of fossils for their economic and aesthetic virtues. Morell's title- "Dustup in the Bone Pile: Academics V. Collectors"- put the issue bluntly.

Although the buying, selling, and trading of fossils has been a part of paleontological practice for centuries, the commercial collection of fossils today has re-emerged into a pervasive and lucrative industry. In 2014, for example, Science noted that in the United States the number of commercial companies driving the legal, and sometimes illegal, selling of fossils is estimated to have doubled since the 1980s (Pringle 2014). Not only is the commercialization of fossils increasingly prevalent; it is also deemed by some as problematic. Indeed, some scientists have gone so far as to describe "the battle against heightened commercialization of fossils to be the greatest challenge to paleontology of the twenty-first century" (Shimada et al. 2014, 4).

Historians of science have documented the birth and growth of American paleontology in the late nineteenth and early twentieth centuries regarding the role of fossil collecting as it evolved from an amateur tradition to an academic practice within museums and universities (Rainger 1991; Brinkman 2010; Rieppel 2012, 2019). Meanwhile, others have discussed the role of fossils as symbols of cultural and national heritage, and sometimes revealing how the growing market value of fossils has caused intense competition between individuals and institutions (Mitchell 1998; Jaffe 2001; Rea 2004; Brinkman 2010; Nieuwland 2019; Rieppel 2018, 2019). Lukas Reippel, for example, addressed the process by which dinosaur specimens were priced in the late nineteenth century (Rieppel 2015). Drawing on the discovery of an exceptional fossil quarry in Wyoming, Reippel demonstrated that the general economic principle of supply and demand was just one component in the valuation of fossils. He argued that more abstract but equally central elements of information exchange and negotiation 
tactics of trust between parties, including concurrent practices in the mineral industry, were instrumental in determining a fossil's monetary value.

Although scholarship has examined how historical rivalries for fossils, fame, and fortune have shaped paleontological practices, it has not investigated the current debate regarding fossil access in light of their increasing scientific and economic worth in the late twentieth and early twenty-first centuries. To be clear, the commercial collection of fossils is not new. But it is different. Today, commercial fossil collection has changed as the social structure of the paleontological community has changed, giving rise to new motivations, interactions, and justifications of authority over fossil objects among different stakeholders both within the community and along its periphery. The contemporary controversy over access to vertebrate fossils warrants attention because without study of it we risk misunderstanding the intimate relationship between science and commerce, therefore underestimating its importance in paleontology's history and influence on the practice today.

In this article, I address the story of "Sue" - the largest, most complete, and most expensive Tyrannosaurus rex ever excavated. ${ }^{1}$ First discovered in August of 1990 on ranch land near the small town of Faith, South Dakota, Sue is now on display at one of the world's most prestigious, privately-owned, non-profit institutions dedicated to scientific education and research-the Field Museum of Natural History in Chicago, Illinois. ${ }^{2}$ But how she got there is a long and complicated story, involving a series of very public and heated lawsuits over her possession. From beginning to end, Sue can be physically traced to five different locations, moving between private and public possession along the way. ${ }^{3}$ And at each location, there is a story to be told about the various stakeholders involved and how their assumptions of authority facilitated one of the most divisive episodes of recent paleontological history.

As the subject of one of the most high-profile legal cases (and highly-priced fossil purchases) in paleontology to date, Sue has been widely discussed and debated over the decades (Duffy and Lofgren 1994; Fiffer 2000; Larson and Donnan 2002; Miller 2014). Sue is the epitome of a contemporary paleontological controversy, and while unique, her story is not an isolated event or a solitary example of the interplay between science and commerce (as well as disputes that arise from it). In fact, Sue's story serves as a point of departure for examining the broader debate over fossil access in the late twentieth and early twenty-first centuries. Further, this is not

\footnotetext{
1 "Sue" is also arguably the most popular prehistoric personality on social media with over forty thousand followers on Twitter (@SUEtheTrex). See http://www.chicagomag.com/arts-culture/December2017/Best-Twitter-Use-by-Local-Dinosaur/.

${ }^{2}$ Sue was mounted for display in the Stanley Field Hall in 2000. For nearly two decades, she marked the entrance of the Field Museum of Natural History, but now she is on display in a new gallery hall for the permanent exhibition Evolving Planet. See https://www.fieldmuseum.org/at-the-field/exhibitions/sue-t-rex.

${ }^{3}$ As an object in transit, Sue can be physically traced from five different locations starting from one) where she was found on Maurice Williams' land near Faith, South Dakota to two) the Black Hills Institute of Geological Research in Hill City, South Dakota. She was then transported to three) the South Dakota School of Mines and Technology in Rapid City. From there, she went to four) auction by Sotheby's in New York City and ultimately ended up at five) The Field Museum of Natural History in Chicago, Illinois. There are also other locations that could arguably be added to this list such as Walt Disney World's Animal Kingdom where portions of the skeleton were prepared and California where scans of the specimen were conducted.
} 
a petty debate among those involved in the search, study, and sale of fossil material. Rather, it has important implications for understanding perceptions of who is allowed to assert their authority over material objects (in this case vertebrate fossils). This is of interest to historians, philosophers, sociologists, and scientists alike as it raises philosophical and sociological questions about scientific authenticity, autonomy, and identity.

In this article, I introduce assumptions of authority over access to fossil objects as a lens through which to examine the near decade long custody battle over Sue. Here, assumptions of authority over fossil objects does not necessarily entail ownership. It does, however, entail access from which ownership or expertise claims then follow. One, for example, could own a fossil while not having the expertise (be it scientific, aesthetic, economic, etc.) to determine its worth. Conversely, one could have scientific expertise which they claim as justification for access to a fossil while not having ownership of it. Further, one could claim authority over a specimen on both counts of ownership and expertise. ${ }^{4}$ This lens is productive for two reasons. First, it allows for a more accurate characterization of the various stakeholders (and their motivations) involved in Sue's story, including but not limited to academic paleontologists, commercial fossil collectors, private citizens, government officials, Native Americans, and the general public. Second, assumptions of authority illuminate the process of boundary-work by which individuals and groups constructed or deconstructed boundaries concerning fossil access, then implemented and enforced those boundaries in order to establish authority. This lens also aids in examining why and how such boundaries have been renegotiated throughout the history of paleontology.

Overall, I argue that assumptions of authority are primarily responsible for initiating and sustaining debates over fossil access in the case of Sue. To support this argument, I draw on science studies scholarship as well as literature in the professionalization, commercialization, and valuation of science. While this article is by no means an exhaustive examination of Sue's story or the broader debate at hand, it is a step in that direction, towards a much larger project on the commercial collection of vertebrate fossil material in the United Sates today. ${ }^{5}$

\footnotetext{
${ }^{4}$ For literature on scientific expertise, specifically knowledge expertise, see work in the sociology of science by Harry Collins and colleagues (Collins 2004; Collins et al. 2007; Collins 2010). For related information on the sociological concepts of knowledge control and knowledge control regimes, see Stephen Hilgartner's Reordering Life (2017).

5 The ethical collecting, buying, and selling of fossils introduces a wide-range of issues that vary among countries because of their own unique cultural, political, legislative, and scientific histories. These different contexts affect both the meaning of fossils and the motivations behind the search and study of fossils. Broadly, the topic of fossil ethics concerns both vertebrate and invertebrate specimens. It also concerns various stakeholders from academics, curators, preparators, amateurs, and commercial collectors to politicians, the public, and individuals involved in the black-market fossil trade. For this article and larger project, I focus specifically on Sue's story and the debate in the United States in the late twentieth and early twenty-first centuries. To do so, I build on Lukas Rieppel's scholarship on the valuation of dinosaur specimens in the late nineteenth and early twentieth centuries in the United States (Rieppel 2015, 2019).
} 


\section{The story of Sue}

\subsection{Discovery}

In August 1990, Susan Hendrikson-an experienced explorer and fossil hunterwas prospecting for fossils along a rocky outcrop in South Dakota. Eventually, Hendrikson noted several large vertebrae jutting out from an eroding bluff. Underneath those vertebrae were the fossil remains of a nearly complete, approximately 65 -million-year-old Tyrannosaurus rex. At the time, Hendrikson was working on an expedition with the Black Hills Institute of Geological Research (BHI), owned and operated by brothers Peter and Neal Larson along with colleagues Jim Honert and Bob Farrar. The land they were prospecting and digging on was ranch land belonging to a man named Maurice Williams. The BHI, reportedly bought the skeleton from Williams, writing him a check for five thousand dollars with the words "theropod skeleton" on the check memo line. The BHI then excavated the fossil and began preparing it for study and display at their institute in Hill City, South Dakota (Fiffer 2000, Chapters 1 and 2).

The BHI had been in operation since the early 1970s as a successful-albeit controversial-private establishment dedicated to the commercial collection, preparation, preservation, and sale of fossil material. The business was the culmination of the Larson brothers' childhood passion for fossil hunting, trading, and research. And the fossil Hendrikson found, nicknamed "Sue" in her honor, became regarded as the world's largest, most complete, and most famous $T$-rex ever discovered (Larson and Donnan 2002).

The next year in 1991, Peter Larson delivered a 12-min talk at the 51st annual SVP meeting in San Diego, California. The talk served as Larson's official introduction of Sue to the academic scientific community. At the meeting, Larson announced that Sue would be prepared by the BHI, never to be sold for profit so as to always be available at their institute for scientific research. Larson reportedly invited researchers to study the specimen and had planned to produce an extensive monograph that would involve over thirty scientific contributors. Although a member of SVP, a predominately academic society of paleontologists, Larson's reputation within this community was highly contested because of his commercial interests. Indeed, fellow members worried that Larson, being a well-known fossil trader, might sell the specimen for its economic value which might compromise its scientific value via restricted access to Sue's study and analysis (Fiffer 2000, 37-38).

\subsection{Seizure}

In May 1992, the Federal Bureau of Investigation (FBI) raided the BHI under orders to seize the fossil remains of a dinosaur named "Sue" and to confiscate all documents related to the specimen. United States District Judge Richard Battey issued the warrant on grounds of alleged criminal activity, claiming the BHI had stolen fossil material from federal government property. The warrant also cited violations 
of the Antiquities Act of 1906. United States Attorney Kevin Schieffer authorized the seizure, insisting the specimen be locked in storage at the South Dakota School of Mines and Technology in Rapid City. As far as Schieffer and government officials were concerned, the fossil was federal property (Browne 1992).

Others, however, disagreed. Larson claimed authority over Sue in terms of ownership rights for the reason that Hendrikson had discovered the fossil and the BHI had paid the landowner, Williams, for its removal. Because of this, the BHI decided to "Sue for Sue." They hired a lawyer, Patrick Duffy, who went to court on the institute's behalf, declaring four defendants in the law suit: United States Department of Justice, United States Department of Interior, Cheyenne River Sioux Tribe, and the South Dakota School of Mines and Technology (Fiffer 2000, Chapter 3; Duffy and Lofgren 1994).

From 1992 to 1996, the court oversaw a series of legal battles to answer the elusive but essential question of "Who owns Sue?" According to Steve Fiffer-a lawyer and author of a detailed but arguably biased account of Sue's story-Larson and his institute were the target of a significantly larger investigation into the fossil trade. In fact, in the mid 1980s there were rumors that South Dakota government officials were interested in launching an investigation into the illegal collecting, buying, and selling of fossils across the state. Vincent Santucci, a paleontologist and National Park Service Ranger, was suspicious of Larson and the legality of the institute's practices in general and of Sue's discovery specifically when he learned about where she had been found. As it turned out, Williams' was a member of the Cheyenne River Sioux Tribe and the land where the fossil was found was part of the Cheyenne River Indian Reservation. Technically, the land, being tribal land, was held in trust by the United States Department of Interior. Given this fact, Santucci alerted the National Park Service, who alerted the Cheyenne River Sioux Tribe. The tribe issued a complaint with the United States Attorney, who then authorized the raid on the BHI (Fiffer 2000).

\subsection{Who owns Sue?}

The FBI's raid of the BHI and removal of Sue from the institute drew national attention particularly as the citizens of Hill City took to the streets in protest of the FBI's seizure. With posters and chants of "Free Sue," the people declared the dinosaur belonged to their small town, and they demanded her return. Formally, however, it was the United States Department of Justice and Department of Interior along with the Cheyenne River Sioux Tribe as defendants that asserted their authority as rightful owners of the fossil. On behalf of the former, Schieffer maintained the fossil belonged to the federal government. Gregg Bourland, member and chairman of the Sioux tribe, argued that the land, as well as the fossil on it, belonged to the tribe (Fiffer 2000). The BHI countered their claim in court arguing their authority in terms of ownership given Hendrikson had found the fossil which they then purchased from Williams and labored over Sue's excavation. They also asserted their authority in regards to their expertise and experience in collecting and preparing fossil specimens (Larson and Donnan 2002). 
Interestingly, Williams - the land owner — did not, at least at first, stake his claim as Sue's rightful owner, so he was not yet a formal defendant in court (Fiffer 2000, 66). It was only later that Williams claimed authority in terms of ownership, arguing that he never accepted BHI's check as payment for the fossil but rather for consent to dig on his land (Fiffer 2000, 166). According to Fiffer, William's unexpected assertion of his claim to ownership created more chaos. In response, The Hill City Prevailer published a piece with an open invite to "Stake Your Claim to Sue." ABC News's Primetime Live joined in on the joke too, inviting the individuals who were actually engaged in the legal battle over Sue to explain why they thought they were entitled to own one of the greatest fossils ever found. On national television, Williams not only argued for ownership, but he also revealed his motivations for claiming Sue as personal property. For Williams, it was about the money that would come with such a prized find (Fiffer 2000, 104).

In the paleontology community, individuals were divided over Sue's ownership. For example, well-known paleontologists including Phil Currie, Bob Bakker, and Jack Horner characterized the raid as " "absolutely ridiculous"” (Browne 1992). Bakker-a maverick paleontologist with a degree from Harvard University-testified on Larson and the institute's behalf. As an ally, Bakker argued that Peter Larson was "one of the most competent excavators and preparators of fossils in the business" with a dedication to keeping "meticulous records" and "mounting specimens [better] than many scientists" (Browne 1992).

But not all paleontologists held the same view. As one of the foremost scientific societies, SVP condemned Larson and the BHI specifically, and commercial fossil collection more generally. Michael Woodburne, past president of SVP and current chairman of the Government Liaison Committee, issued a statement declaring the society's extreme concern over "the heightened activities of commercial collectors in recent years" which resulted in the "loss of invaluable, nonrenewable paleontological specimens" (Fiffer 2000, 67). According to Fiffer, the SVP wrote a formal letter to Schieffer endorsing the federal government's raid of the institute and seizure of the fossil. The letter reportedly argued that Larson and the institute did not have the established scientific expertise to properly prepare such a significant specimen (Fiffer 2000, 74). Among certain paleontologists, assumptions of authority concerned both perceptions of legal ownership as based on the law and opinions of scientific expertise.

\subsection{Decision determined}

From 1992 to 1994, there were four trials regarding Sue's ownership. The first two court cases in 1992 were related to Sue's seizure. In these cases, the BHI challenged the government for taking Sue from their possession, but the court ruled the seizure was justified. The latter two court cases involved a legal custody battle over Sue's ultimate ownership. ${ }^{6}$

\footnotetext{
${ }^{6}$ See https://caselaw.findlaw.com/us-8th-circuit/1097492.html.
} 
In 1994, Judge Battey ruled that Larson and the institute were not the rightful owners of Sue. As discovered earlier, Williams' was a member of the Cheyenne River Sioux Tribe and the land where the fossil was found was part of the Cheyenne River Indian Reservation. As such, William's land was held in trust by the United States, meaning the federal government had primary ownership of the land and any natural resources found on it. Williams only had secondary ownership which legally required him obtain permission from the United States Department of Interior for the sale of the land as well as any resources from it. In this case, Judge Battey ruled that Sue was "land"-real property - and was subject to the statutes regarding the buying and selling of trust land. Consequently, Williams had no right to sell the fossil without governmental permission so Larson's payment to for the dinosaur was null and void (Fiffer 2000, 117-118).

\subsection{Larson's fate}

In a separate legal action, the United States Department of Justice issued a 33-page, 39-count indictment against the BHI. The Department of Justice named both Larson brothers and two colleagues as defendants. In total, there were 154 criminal charges involving instances of theft of government property, false statements to government agencies, wire fraud, money laundering, and other accusations. Of these, there were 148 felonies and 6 misdemeanors. Fiffer commented that if convicted of all crimes, Peter Larson, for example, could face approximately 300 years in prison and $\$ 13$ million in fines (Fiffer 2000, 146).

In the end, most charges were dropped, save for two felonies and two misdemeanors. The two felonies involved Peter Larson's failure to report money taken out of and into the United States on two separate occasions (over 30 thousand dollars in the first instance and 15 thousand in the second). His misdemeanors involved the illegal collection of a fossil from federal property and the retainment of another. In 1996, Judge Battey sentenced Larsen to 2 years in a minimum-security prison (Browne 1996). Interestingly, these convictions were for crimes related to commercial fossil collection but not related to excavation of Sue.

\subsection{Sue's fate}

Following the 1994 ruling, Williams asked for government permission to sell Sue. His request was granted. In 1996, Sue was shipped to New York City for auction by Sotheby's. The next year, bidding began at $\$ 500$ thousand. Sue was sold less than ten minutes later but for a much higher price (Browne 1997). Indeed, Sue was purchased by the Field Museum of Natural History for over $\$ 8$ million of which nearly $\$ 7$ million was paid to Williams. The Field Museum was able to afford such a high price thanks to financial assistance from the McDonald's and Disney Corporations, as well as several other patrons. At the time, academic paleontologists worried that the dinosaur, a rare and scientifically significant specimen, might be sold to a private owner and lost to science. In fact, the Field Museum is a private non-profit institution, but one serving the scientific community and general public. In light of this, 
scientists were relieved, feeling that her preparation would be conducted by expert technicians and researchers from which the specimen would then be available for study by fellow scientists and put on public display.

In summary, this synopsis spotlights the complex network of individuals involved in Sue's story from academic paleontologists and commercial collectors to private citizens, government officials, Native Americans, and the general public. The legal battle over Sue typifies the debate over fossil access in the United States, and the role of scientists and fossil dealers in accessing exceptional fossil finds of high media, monetary, and scientific value. Both individuals and groups staked claim over Sue but justified those claims through different arguments based on different values and assumptions of authority. Larson and the BHI, for example, assumed authority over Sue in terms of ownership and expertise. The United States Department of Justice and Department of Interior, along with the Cheyenne River Sioux Tribe, assumed ownership for legal reasons. Scientists, particularly paleontologists of SVP, assumed authority over Sue on the basis of the specimen's research value, their own scientific expertise, and the need for public accessibility.

\section{Fossils and values}

In 1989, the year before Sue's discovery, invertebrate paleontologist Norman Gary Lane delivered his Presidential Address_-"Paleontology: The Academy and the Marketplace" - to the Paleontological Society (PS) (Lane 1989). Founded in Baltimore, Maryland in 1908, the PS is an international organization dedicated to vertebrate and invertebrate paleontology, and maintains two research publications, Journal of Paleontology and Paleobiology. The PS, alongside SVP, are two of the most prestigious research societies dedicated to the study of evolutionary history as depicted through the fossil record. In his opening address, Lane noted that most presidents spoke of their research interests. However, this year, he was "breaking from tradition" in light of "serious matters" that "deserve widespread discussion" (Lane 1989, 259). For Lane, the society faced several problems, one being its relationship with "amateur fossil collectors" and another being its official position on access to "fossil sites and fossil collecting" (Lane 1989, 259).

Lane noted that both paleontologists and amateur fossil collectors have had negative experiences and frustrations in their interactions with one another. From his perspective, amateur fossil collectors were essential to paleontological practice, thus scientists should cultivate respectful working relationships with them to ensure access to fossils in hopes they could be prepared, catalogued, preserved, and ultimately studied for generations to come. For Lane, cultivation required education, which also required clear distinctions between the many people engaged in the search and study of fossils. Here, he specifically spotlighted the general confusion between the "scientific paleontologist" and "commercial dealer." According to Lane, "most amateur collectors [...] use the term 'professional' to mean any person who earns his or her principal income through fossils, whether that income is derived from teaching and research or from the sale of fossils - thus lumping scientific paleontologists and commercial dealers together" (Lane 1989, 259). This misconception 
among amateurs regarding the social structure of the paleontology community was problematic, at least according to Lane and the PS. While both scientists and fossil dealers drew a livelihood from fossil objects, their motivations behind their work were not necessarily the same.

Lane conceded that another topic, fossil sites and fossil collecting, was a further source of "disagreement" and "controversy"-much of which centered around access to fossils on private and public lands (Lane 1989, 260). As far as he was concerned, scientific paleontologists were deeply divided over this issue of authority and access: "Some believe that collecting restrictions are necessary, on all or on some part of the paleontological population. Others believe that no restrictions of any kind should be imposed on anyone" (Lane 1989, 260). For example, invertebrate fossils, while scientifically significant, are often more common so were far less contentious regarding fossil access. Conversely, vertebrate fossils such as dinosaur fossils are usually considered rarer, thus more desirable for their scientific, economic, and social value. While Lane did not provide a clear-cut explanation of the issues or remedy for this problem, he hinted at what he thought were the best first steps towards community consensus. For Lane, the "ultimate solution" was one of "education" and not "permits" (permissions) for who can or cannot contribute to the search and study of fossils (Lane 1989, 260). Here, he appeared interested in building some boundaries around paleontological practice not necessarily to exclude people from participation in it, but to clarify the different individuals, efforts, and affairs that contributed to the paleontology community, bringing with them unique values and assumptions of authority.

Lane's speech was indicative of two points. First, it highlighted that the search for and study of fossil objects attracted disparate stakeholders from amateurs and educators to scientists to fossils dealers. Indeed, throughout paleontology's history, fossils have functioned as "boundary objects" or points of interest between groups (Star and Griesemer 1989) As sociologists of science argued, boundary objects could be material objects, or even theoretical concepts, shared by multiple communities but used in different ways or valued for different reasons. Drawing on the Berkeley Museum of Vertebrate Zoology as an example, Susan Star and James Griesemer introduced the notion of boundary object to explain the ways amateurs and scientists worked together to produce scientific knowledge. In doing so, they identified various boundary objects from the collections and specimens themselves to field notes, documents, and maps. In "developing, teaching and enforcing a clear set of methods to 'discipline' the information obtained by collectors, trappers, and other non-scientists" boundary objects ultimately functioned to "maximize both the autonomy and communication between worlds" (Star and Griesemer 1989, 404). On the one hand, these objects were stable enough to warrant recognition and successful translation across social worlds (from the field to the museum). On the other hand, they were flexible enough to fulfill other purposes in alternative contexts (Star and Griesemer 1989, 393).

As a material object, Sue was a rather obvious boundary object from which scientists and fossil dealers perceived differently in terms of value. For some, Sue was a scientifically significant specimen. Others appreciated the fossil for aesthetics. Some people, like the public citizens of Hill City, saw her as a symbol of pride for their 
town and state. For the Sioux tribe and government officials, the fossil was valuable as a legal matter within a larger history of property ownership. Further, her scientific significance, aesthetic disposition, and cultural importance afforded her an economic value as well. And to complicate the matters, these values were not necessarily mutually exclusive.

Second, Lane's speech underscored a growing confusion and subsequent contention between these stakeholders (namely the "scientist" and "professional") as it related to their investment with fossils. In fact, historians have highlighted the challenge of categorical definitions because how people self-identified and interacted with each another was historically and socially contingent (Secord 1994, 2002; Barrow 2000; Lucier 2009; Rieppel 2015, 2019). ${ }^{7}$ In the late nineteenth-century America, naturalists and collectors were part of a community in which natural history and commerce were distinct practices but ones of collaboration and mutual benefit with collectors receiving financial rewards for specimens and naturalists earning credit or prestige for their expertise in studying them. At this time, "there was no such thing as a professional scientist," explained Paul Lucier. "Professional' and 'scientist' were terms that described two very different individuals with very different social roles. The professional was engaged in money-making enterprises; the scientist was disengaged from such pursuits" (Lucier 2009, 732). Although distinct, it did not entail that professionals were unconcerned with their moral reputation in terms of trust. Nor were scientists immune from the financial influences of market economy. As Lucier argued, the "professional" and "scientist" are "occupational categories that reveal and reflect the changing relations of science to money and market capitalism" (Lucier 2009, 705).

This began to shift in the early twentieth-century as paleontologists consciously distanced themselves from commercial interests. During the Gilded Age, as Lucier argued, "scientists' came to distrust commercial patrons and feared that money would corrupt American science" (Lucier 2009, 705). But as Reippel demonstrated, scientists' movement towards autonomy coincided with the rise of American business tycoons from Andrew Carnegie to Marshall Field (for whom the Field Museum of Natural History is named). In what he referred to as a "strategic alliance with mutual benefits" and "no strings attached" policy, paleontologists drew on "a steady stream of funding" while "wealthy capitalists" touted their support of "a genuinely altruistic endeavor" (Rieppel 2019, 11). Through funding via philanthropists as well as financial support from affluent universities, paleontologists were more or less able to maintain autonomy in light of a growing capitalist society along with the continuation of the commercial fossil trade (Lucier 2009; Rieppel 2019).

All of this raises questions about the valuation of material objects, particularly those of scientific value. As Marion Fourcade noted, we assign monetary value to nearly every aspect of society, the tangible and intangible alike. Specifically, we attribute economic value to natural resources. Here, she argued our need to know "why" money is used as a metric of worth, "how" such a metric is conceived and

\footnotetext{
7 For earlier scholarship on professionalization of science and amateur traditions, see Reingold (1979), Keeney (1992), Barrow (1998), and Smocovitis (1996).
} 
employed by individuals or groups in a given society of a specific place and time, and "what" the economic valuation of natural resources means for society (Fourcade 2011). Fourcade argued that monetary attributions are not just the product of a society's legal, political, and economic institutions, but they feed back into the culture they came from, influencing and reinforcing existing social practices. "What we strive to understand here is a comprehensive empirical cycle: what goes into valuation methods, what comes out-what, substantively, gets 'constructed'-and what the consequences of these constructions are" (Fourcade 2011, 1724). ${ }^{8}$ Fourcade put the point this way, "Economic valuation is so revealing precisely because it is so much more than a process of monetary commensuration: it is, much more powerfully, a process of 'definition' or social construction in a substantive sense [...] which incorporates all kinds of assumptions about social order and socially structured imaginaries about worth" (Fourcade 2011, 1769). To flesh this out, Fourcade mentioned the concept of "economies of worth" in order to make the point that "money represents just one axis by which we commonly assess what things are "worth" (Fourcade 2011, 1725). Put another way, individuals and institutions often embrace multiple and sometimes opposing beliefs about what kind of value (and how much of it) can be attributed to natural resources and the environment (Fourcade 2011, 1725). This was precisely the situation, a negotiation of different economies of worth, that academics, and fossil dealers faced.

In the late 1970s, nearly 10 years before Lane's speech, a number of fossil dealers and numerous institutions, including Larson and the BHI, founded the American Association of Paleontological Suppliers (now the Association of Applied Paleontological Sciences) (AAPS) - a society dedicated to commercial fossil collection. ${ }^{9}$ The AAPS's initial purpose was "to expand scientific knowledge and public awareness in the field of paleontology through preservation and distribution of paleontological remains." In pursuit of this, they stated that "all materials collected for this purpose shall be obtained in an ethical and professional manner in order to preserve paleontological specimens otherwise lost to science by the destructive agents of weathering, and/or human endeavor" (Raup et al. 1987, 54). Further, the association recognized the need to respect different interests of various individuals that the science of paleontology brought together, claiming that their "economic objectives"

\footnotetext{
${ }^{8}$ Fourcade draws on Ian Hacking's work that points to specific sociohistorical products (monetary values) and their sociohistorical processes (economic valuation) as objects of interest when discussing social construction.

${ }^{9}$ AAPS founding members included the following commercial fossil and mineral businesses: Black Hills Minerals (Black Hills Institute of Geological Research) represented by Peter Larson and James Honert of Rapid City, South Dakota; Geological Enterprises represented by Allen Graffham of Ardmore, Oklahoma; Geoscience Enterprises represented by Bob Howell of Roachdale, Indiana; Maloney's Fossils represented by Tom and Hilda Maloney of Willows, California; Melloy's Fossils represented by George Melloy of Bethlehem, Pennsylvania; Tetla represented by Gerald Berry of El Paso, Texas; The Bug House represented by Bob Harris of Delta, Utah; and Ward's Natural Science Establishment represented by Steve Bryson of Rochester, New York. Today, the AAPS regards itself as a "professional association of commercial fossil and mineral collectors and preparators" that exists for "promoting ethical collecting practices and cooperative liaisons with researchers, instructors, curators and exhibit managers in the academic and museum paleontological community." See http://www.aaps.net/history-of-aaps.htm.
} 
should "always reflect the desire to meet both the research and educational needs of the scientific community and the interested public" (Raup et al. 1987, 54). For the AAPS, science and commerce were two sides of the same coin. Educational objectives and public interest need not be excluded either. While the formation of the AAPS certainly signified the growth of commercial fossil collection as a pervasive industry, its mission signaled a desire to be recognized as a professional, ethical, and legitimate contributor in the paleontological community. This move was just as important as it was polemic.

\section{Fossil regulation before Sue}

In 1984, the National Academy of Sciences formed the Committee on Guidelines for paleontological collecting in response to this increasing interest in fossils from various stakeholders (Raup et al. 1987). The committee included thirteen members ranging from academic vertebrate and invertebrate paleontologists to fossil dealers, industry representatives, as well as state and federal government officials. Their objective was to discuss the protection, preservation, access to, and ownership of vertebrate and invertebrate fossil material. Specifically, they sought to "to develop a general statement on the appropriate role of government in the regulation (or lack thereof) of field collecting of the fossils of prehistoric plants and animals" (Raup et al. 1987, vii). ${ }^{10}$ Much of their discussions were about existing assumptions regarding the definition and significance of fossils. They also shared thoughts on who should have the authority to access them.

As far as the committee was concerned, they were asking an "apparently straightforward question" (Raup el et al. 1987, 216). "How should government protect and preserve fossils of extinct plants and animals while at the same time allowing other legitimate uses of the land and encouraging the scientific study of fossils?" (Raup el et al. 1987, 216). The answer was far from simple for three reasons.

First, there was no federal law regarding the collection of paleontological material on public land. Consequently, the authority to employ and enforce policies concerning fossil collection fell to numerous federal land management agencies such as the Bureau of Land Management (BLM), the National Park Service (NPS), and Forest Service (FS). ${ }^{11}$ These agencies had authority to determine who was allowed

\footnotetext{
10 At a meeting in Farmington, New Mexico, in 1981, attendants were concerned with the area's "surface coal mining" issue and its impact on "scientific and hobby collecting of fossils by scientists and hobbyists" (Raup et al. 1987, vii). This meeting, among other issues that had surfaced in past years, were responsible for the committee's initial formation.

11 In 1976, the Federal Land Policy and Management Act (FLPMA) granted the BLM the authority to regulate the use of public lands via leases, licenses, and permits. Interestingly, the FLPMA did not explicitly mention paleontological material. Instead, it only mentioned archeological resources. However, in writing their final report on fossil collection, the committee (nearly ten years after the introduction of the FLPMA) noted that the act did in fact list "several references to 'scientific values' of the public lands, which would presumably include fossils (at lease those of scientific values)" (Raup et al. 187, 224). On the other hand, the NPS — which was also under that Department of Interior-provided a much more straightforward statement about its position on fossil collection. According to the Organic Act of 1916, the NPS's job was to manage national monuments and parks for their conservation, which meant
} 
to collect fossils via use of issued permits or other regulatory protocol. This also meant that fossil collectors-scientists, hobbyists, and dealers alike-were responsible for educating themselves of these policies if there were any, and understanding their disparities so to abide accordingly. Doing so could be a near impossible task. Indeed, there were more than sixty federal agencies with some form of regulatory responsibility concerning fossil collection on public land (Raup el et al. 1987, 2). For the most part, however, these agencies had no specific policies and if they did, they were inconsistent, ambiguous, or difficult to enforce.

Next, the committee noted that several government agencies held what were erroneous or problematic assumptions about paleontological practice. ${ }^{12}$ For example, most agency officials assumed that paleontological material could be regulated in the same way as archeological material, the latter for which there was a clear-cut law. The Antiquities Act of 1906 specified how archeological sites and specimens on land owned or controlled by the government were to be protected for the natural and cultural heritage of the United States. The act did not specifically speak to fossil remains in the way that it addressed archeological artifacts, but it had been used to justify the arrest and trial of Farish Jenkins, a Harvard University paleontologist accused of illegally collecting fossils on public land. ${ }^{13}$ According to the

\section{Footnote 11 (continued)}

strictly prohibiting the tampering with or removing paleontological material found on NPS property. The Department of Interior and the Department of Agriculture also exercised authority over fossil collection. Given different federal policies, some states adopted their own legislation on fossil regulation. At the time the committee wrote their report at least twenty states from had proposed qualifications and requirements for particular permits and even penalties for not abiding by the law (Raup et al. 1987, 226-233).

12 The committee found that current land management agencies had made several other assumptions in the creation of policies regarding fossil protection on federal land. For example, they noted that land management agencies' respective policies appeared to be based on six principal assumptions, namely one) that "fossils constitute a valuable, nonrenewable resource," two) that "assessing the importance of the fossils existing on a tract of land is possible and desirable," three) that "the land manager has an obligation to inventory fossils, four) that "the land manager has an obligation to preserve and protect fossils in rocks wherever possible, five) that the "collecting of fossils should be limited and controlled, with the general objective of minimizing the amount of collecting," and six), that "collectors should provide detailed plans before collecting and report their findings afterward" (Paleontological Collecting 1987, 21-22). The committee did not find issue with these assumptions and their application on a case-bycase basis. However, they did object to their use as a blanket statement for all paleontological sites and specimens across the country. As far as the committee was concerned, there were too many unnecessary, inconsistent, or ineffective regulations on fossils.

${ }^{13}$ In 1974, Harvard University professor and paleontologist, Farish Jenkins, was arrested for collecting fossil remains on BLM property. Jenkins argued he had unknowingly crossed an unmarked boundary while fossil hunting in Montana that put him on land owned by the BLM. He was charged under the Antiquities Act which maintained he collected fossils on public land for which he did not have a permit. The formal charge maintained that he lacked permission for the removal of any historic or prehistoric ruin or monument, or any object of antiquity. The key phrase in this law was "object of antiquity." However, it was not necessarily clear that "object of antiquity" as outlined in the legislation referred to paleontological material. Based on the circumstance as well as a former ruling from 1912 (United States versus Diaz), the phrasing was deemed to be unconstitutionally vague and the charge, as well as the case, was dropped. The Department of Interior later declared that Antiquities Act would only apply to archeological material, not paleontological material. Despite this declaration, the definition of paleontological materials and their relations to archeological materials remained a source of confusion (Malmsheimer and Hilfinger 2003, 592-98). 
committee, this was but one example of "overzealous regulatory activities of federal agencies"-much of which was a result of a misunderstanding of the differences between archeological and paleontological material (Raup el et al. 1987, 2). ${ }^{14}$ They also argued the need for a legal understanding of the difference between archeological and paleontological material in order to avoid future issues. Interestingly, this case was not an isolated instance in which government officials assumed likeness between paleontological and archeological material. In 1992, the federal government cited the Antiquities Act of 1906 to justify the FBI's actions in confiscating Sue from the BHI.

Lastly, the committee claimed that the paleontology community held assumptions regarding the incompatibility of scientific and commercial interests, thus further problematizing the subject of fossil access. As far as the committee was concerned, commercial fossil collection was "one of the most sensitive and difficult aspects of the overall problem" (Raup el et al. 1987, 5). For the committee's purposes, they defined commercial fossil collection as the general collecting, buying, and selling of paleontological material with other dealers or hobbyists on a national or international scale. They often traded or sold their finds to private individuals as well as public groups such as schools, universities, museums. A number of academics, explained the committee, vehemently opposed the selling fossils for economic gain as a matter of principle. The committee's final report, for example, noted that " $[\mathrm{m}]$ any paleontologists find the sale of fossils repugnant on esthetic and moral grounds and because the increasing use of spectacular fossils as art objects encourages overcollecting of rare species" (Raup el et al. 1987, 5). ${ }^{15}$ In this same report, committee members highlighted the positive impact of commercial collectors, explaining that fossil dealers were concerned with advancing the education and production of knowledge in paleontology, thus meeting both personal economic and public educational interests (Raup el et al. 1987, 12-13). Across government agencies and the

\footnotetext{
14 The committee defined "paleontology" as "the study of prehistoric, nonhuman life." They also explained that paleontology, as opposed to archeology, was most "closely allied with geology and biology." Archeology, on the other hand, they defined as a "subdiscipline of anthropology" that "deals with the remains of past human populations." They further defined archeology as the "systematic study of antiquities" of which is "limited to the materials produced by mankind." In practice, they argued for a definite difference between the two sciences in terms of its theory and practice: "Paleontology has developed techniques and procedures different from those of archeology, and the nature of paleontological collecting and the uses of collections are very different from those of archeology" (Raup et al. 1987, 11-12). 15 SVP condemned commercial collection for this reason, and their adoption of an official opinion to the opposition of commercial fossils collection reportedly impacted the museum fossil market. According to the committee's final report, "The general feeling against the sale of fossils has led recently to an agreement among the major natural history museums to stop selling fossils in museum shops. It has also led to a number of attempts to limit or prohibit all fossil collecting for commercial purposes." Based on the committee's investigation, the commercial fossil collection problem seemed to be the most controversial in the field of vertebrate paleontology and in the context of western public lands in the United States. In the committee's effort to both speak with and take a poll of the SVP community, they found that a majority of vertebrate paleontologists "felt strongly" that "fossils from public lands should remain public property." Overall, the committee concluded that the "antipathy toward commercial collectors" was "most strongly held by members of this Society" (Raup et al. 1987, 13).
} 
paleontology community, there were different assumptions concerning a fossil's value and a commercial collector's intentions regarding their access to it.

After a 3-year discussion and a 200-page report of serious "soul-searching," the committee concluded that in regards to fossil collection and preservation on federal land that the "science of paleontology" would be "best served by unimpeded access to fossils and fossil-bearing rocks in the field" where "access" was defined to include "all collecting and removal of fossiliferous material for study and preservation" (Raup el et al. 1987, 2). In other words, it appeared the committee was in favor of reducing rather than promoting regulation in order to encourage fossil access. However, they were quick to note that this stance did not imply a deliberate disregard for paleontological protections: "If taken out of context, these recommendations carry the unfortunate implication that the Committee members do not think fossils are important enough to 'protect and preserve.' Nothing could be further from the truth. We all recognize and appreciate the great importance of fossils both to science and to society, but we also realize that an uncollected and unstudied fossil is of no value" (Raup el et al. 1987, 3).

Rather than supporting more regulations, they offered the following recommendations. First, they supported a uniform federal policy, although not necessarily a law, on paleontological collecting. They were also in support of the idea that each state should adopt a uniform policy for collecting on state-owned land. The third recommendation suggested that all federal land should be available for scientific collecting without a permit, and that activities regarding quarrying or commercial collecting should also be allowed but with permit permission. Finally, the committee suggested that any scientifically significant fossil must be reported, then deposited in an appropriate public institution (Raup el et al. 1987, 3-4).

This conclusion was an effort to balance the interests of academics, amateurs, commercial collectors, and the general public in terms of fossil access while simultaneously protecting the fossils themselves as natural, nonrenewable resources. In the end, however, the Secretary of Interior "disregarded the recommendations" altogether. The Secretary was reportedly of the opinion that " fossils do not constitute a resource requiring the degree of management attention initially proposed by the Department [of Interior]"' (Malmsheimer and Hilfinger 2003, 603). Despite the committee's efforts, there was no change in law or even policy. Regulation was left to federal government agencies, and stakeholders were left to make sense of the policies, including their ambiguities. At the time of Sue's discovery in 1990, this was the landscape of political assumptions that informed her significance and led to a decade-long custody battle over her ownership. 


\section{Fossil regulation after Sue}

In 1992 - the same year that the FBI confiscated Sue from the BHI-the Vertebrate Paleontological Resource Preservation Act (VPRPA) was introduced to Congress by Democratic Senator Max Baucus of Montana for consideration. ${ }^{16}$ The bill sought to create and enact a uniform federal policy for vertebrate fossil collecting, distinguishing them from archaeological and cultural resources to be managed in consultation with paleontologists. According to the act, the collection and excavation of vertebrate fossils on federal land would be open to academic and amateur collectors under a permit system. However, the bill barred commercial fossil collection. Ultimately, the VPRPA did not attract much support, dying in the Senate and never making it to the House (Malmsheimer and Hilfinger 2003, 604). In the years after that, the BLM and FS proposed their own regulations but to no avail (Malmsheimer and Hilfinger 2003, 604-605). Then in 1996, Tim Johnson, a representative and republican from South Dakota, introduced the Fossil Preservation Act (FPA). Unlike the VPRPA, the FPA spoke to all fossil material, vertebrate and invertebrate alike. The bill attracted eleven co-sponsors but never made it to the Senate (Malmsheimer and Hilfinger 2003, 605-606).

In 2000, amidst the aftermath of these repeated legal efforts, the United States Congress requested a report to weigh the need for a "unified federal policy" on the "collection" and "preservation" of "fossils" that would "maximize the availability of fossils for scientific study" (Assessment of Fossil Management on Federal \& Indian Lands 2000, 7). The 50-page-report, "Fossils on Federal and Indian Lands," was issued by the Congressional Research Service and by the Secretory of the Interior with input from several agencies including the FS, BLM, NPS, Bureau of Indian Affairs, Bureau of Reclamation to the Fish and Wildlife Service, United States Geological Survey, and the Smithsonian Institution. Interestingly, the consulting agencies concluded that a basic level of policy uniformity regarding fossil regulations was already in existence. Consequently, they recommended new principles (as opposed to a uniform policy or law) to guide administrative governmental actions moving forward. ${ }^{17}$

However, efforts to instate a federal law on fossil governance on federal land did not stop there. A year after the aforementioned report was published in 2000, the Paleontological Resource Preservation Act (PRPA) was introduced by James McGovern, a representative and democrat from Massachusetts (Dalton 2001). The bill was strongly supported by organizations like SVP and PS. The bill was also supported by twenty-six members across party lines but was slow moving and failed

\footnotetext{
$\overline{16}$ See https://www.congress.gov/bill/102nd-congress/senate-bill/3107.

17 They recommended seven basic principles which laid out various assumptions about the value of fossils. Here, they claimed that one) fossils are a part of the country's heritage, two) that most vertebrate and three) some invertebrate fossils are rare, that four) penalties for theft should be strengthened, that five) effective stewardship of fossils requires accurate information and inventory, that six) federal fossil collections should be made available for research and public education, and that seven) federal fossil management should optimize opportunity for public involvement (Assessment of Fossil Management on Federal \& Indian Lands 2000, 8-10).
} 
consideration by House subcommittees before Congress adjourned (Malmsheimer and Hilfinger 2003, 611).

Despite apparent support, nothing came of the bill that year. According to Smithsonian Magazine, "The delay, some proponents believe, stems from some western lawmakers' reluctance to add any regulations regarding public lands." Indeed, "If passed into law, the act would require that only trained, federally certified professionals be allowed to extract fossils from public lands-and would substantially increase penalties for illegal fossil excavation" (Webster 2009). Specifically, organizations from the AAPS to the American Federation of Minerological Societies were opposed to the legislation because they felt such a law would "cause 'fossils [to] disintegrate shortly after their exposure by erosion' because the bill will 'make the... public land[s] a hunting preserve for a privileged few at the expense of permanent loss of most fossils to erosion"" (Malmsheimer and Hilfinger 2003, 610). In other words, these organizations felt this legislative would promote the destruction, not protection, of fossils and would reinforce the assumption that academic paleontologists should have authority over fossil material to the exclusion of other stakeholders such as commercial collectors. Given the controversy around the legislation, and the fact that the bill was never completely considered before Congress dismissed that year, this version of the PRPA was left dead in its tracks (Malmsheimer and Hilfinger 2003, 611).

In 2009-nearly 10 years after Sue was sold at auction for over $\$ 8$ million and nearly 20 years of repeated legal efforts to instate regulations around fossil collection and preservation - a second version of the Vertebrate Paleontological Resources Preservation Act (PRPA) was finally officially signed into law. The act was approved by President Barack Obama as part of the Omnibus Public Land Management Act ("Fossils Protected in US Land Legislation" 2009). For many academic paleontologists, this was a landmark victory. For the first time in their profession, they had successfully secured the passing of a federal law that would limit public access to vertebrate fossils on federal land. ${ }^{18}$

In short, the PRPA required a permit process for anyone interested in the collection of any vertebrate fossil of scientific significance on federal land. The permit process as overseen by the Secretary of Interior appeared to favor academic paleontologists as opposed to commercial fossil collectors. Here, the law claimed that the Secretary would only issue a permit if "the applicant" was "qualified to carry out the permitted activity" and if "the permitted activity" was "undertaken for the purpose of furthering paleontological knowledge or for public education" ("Paleontological Resource Preservation Act" 2009). Thus, the Secretary would be responsible for determining who would, and who would not, be eligible to collect fossils on federal land. At the same time, however, the act still allowed the "casual collecting" of fossils given that collecting was limited to one) a "reasonable amount" and two) "common invertebrate and plant paleontological resources for non-commercial

18 See http://vertpaleo.org/the-Society/Advocacy/Paleontological-Resources-Preservation-Act.aspx. 
personal use" ("Paleontological Resource Preservation Act" 2009). ${ }^{19}$ The Secretary also assumed authority for determining what it meant to be qualified applicant, as well as the meaning of terms like "reasonable amount" and "common invertebrate and plant paleontological resources" ("Paleontological Resource Preservation Act" 2009). For most of the academic paleontological community, this legislation marked a move in the right direction, a direction that seemed to favor their motivations and assumptions of authority regarding fossil collection.

SVP, for example, was in "strong support" of the PRPA. Indeed, such a law had been a long time coming. SVP agreed with the mandate that scientifically significant specimens be "collected only by qualified researchers who obtain a permit and agree to deposit the fossils in public institutions that will ensure their future availability to researchers and the public" ("Paleontological Resource Preservation Act"). For many academic paleontologists, the law would not only protect fossils, but it would also safeguard their careers from commercial fossil collection, an activity they feared was contaminating their science and contributing to the loss of valued paleontological knowledge. ${ }^{20}$ In other words, the PRPA reinforced scientists' authority in terms of assumed expertise and legal access to fossils on public land.

\section{Assumptions of authority}

Despite the PRPA's passing in 2009, fossil access remained a contentious topic so much so that Science published a four-page article about the issue (Pringle 2014). The article, written in 2014, was prompted by a recent auction in New York City where several high-profile and highly controversial dinosaur specimens were up for grabs. "The Dueling Dinosaurs" and their $\$ 7$ million price tag served as the main attraction. ${ }^{21}$ Given its uniqueness, some said the specimen would sell for nearly $\$ 9$ million. In the end, however, the highest bid was just over $\$ 5$ million, thus falling $\$ 2$ million short of the predicted price (Pringle 2013). "When auction day rolled around," reported Pringle for Science, "most of the rare skeletons, including the Dueling Dinosaurs, failed to sell. The final bids were lower than the owners' minimum prices, suggesting a softening market for fossils. That was welcome news for paleontologists who oppose putting price tags of any kind on scientifically important specimens. But the high-profile auction exposed a growing schism in American

\footnotetext{
19 The PRPA also stated that "the permitted activity" to be "consistent with any management plan applicable to the Federal land concerned" and that "the proposed methods of collecting" would "not threaten significant natural or cultural resources." See "Paleontological Resource Preservation Act" (2018).

${ }^{20}$ In the past twenty years, there have been other high-profile cases on the legal and illegal excavation of dinosaur specimens. For examples, see Webster (2009), Lavine (2005), and Switek (2009).

21 Clayton Phipps, a commercial collector, found the specimen in 2006 on private land in Montana. With permission from the land owner, Phipps excavated the find and set out to sell it to whomever would offer the best price for it. He expected a decent profit given that the fossil find was both aesthetically and scientifically significant. Phipps' Dueling Dinosaurs were just what the name implied, two dinosaurs seemingly interlocked in battle. Further, one specimen appeared to be a new species of the Ceratopsidae family, while the other was a special specimen of the Tyrannosauridae family whose study might settle an intense dispute about variations between juvenile and adult tyrannids (Pringle 2013).
} 
paleontology, between those who sell fossils as merchandise and those who regard them as scientific data" (Pringle 2014, 364). Indeed, the entire affair was indicative of a bigger issue unlikely to get smaller anytime soon.

While some praised the PRPA, others on both sides of the debate were not entirely satisfied. Some commercial collectors, for example, felt legislation placed restrictions on their work and livelihood. Specifically, they claimed they were often denied permits, thus denied access to collect fossils on federal property. Instead, they argued that permits were only being issued to academic paleontologists. According to Pringle, Michael Triebold-a commercial collector and AAPS former president-maintained that "public lands" had become the "private sandbox" for "institutional collectors" who were considered "qualified"” (Pringle 2014, 367). As far as he was concerned, the law favored some (academic paleontologists) and marginalized others (commercial collectors). Triebold suggested Congress offer commercial collectors permits, and therefore permissions, to work on public land but in exchange for royalties on sales.

At the same time, there were paleontologists who thought legislation (although seemingly in their favor) did not go far enough to bar commercial collectors from fossil access. Indeed, they wanted fossils protected on both public and private land as was, and still is, the practice in other countries like Canada. ${ }^{22}$ The fact that there was no fossil protection on private land was problematic. According to Pringle, Thomas Carr-a paleontologist at Carthage College in Wisconsin-believed that federal government should draw on the Constitution, specifically the eminent domain clause, to protect important dinosaur fossils. Invoking this clause would allow government to take private land for public use given the landowner's appropriate compensation. Pringle quoted Carr who explained how this would work: "If the federal government could be convinced that [scientifically important] fossils fall under the definition of 'land, ... then possibly they could be seized and the people who collected the specimens could be compensated for the expense of collection, salaries, and whatever monetary value you place on fossils" (Pringle 2014, 367).

Today, the debate around the ethical collecting of fossil material is highly variable, but the loudest voices in community tend to paint it as a binary conflict, an "us-versus- them" situation. Academics on one side of the debate have argued that what is at stake is the loss of scientifically significant fossils from the public domain: "Where fossils are informative-because they can provide data on systematics, stratigraphy, morphology, function, ontogeny, paleoecology, and so forth-they are significant. [...]. In order to avoid the ever-increasing loss of such fossils to commercialism, which undermines collections-based scientific research and leads to further cuts in funding and job opportunities, the scientific significance of fossils must be increasingly emphasized" (Shimada et al. 2014). The fossils themselves as objects of

\footnotetext{
22 The 2009 PRPA only applied to fossils on public lands. Fossils on private land were a different matter. Under the law, fossils found on private land could be sold to anyone for any price, given the seller has permission from the landowner. It is often standard practice for the fossil hunter to provide a percentage of the profit to the landowner. The AAPS, for example, has formally provided a sample license for commercial collectors which lists a ten percent baseline cut for the landowner. See http://www.aaps.net/colle cting-contract.html.
} 
information were at stake, but so were the professions - and the paychecks —of the scientists who study them. Their argument's underlying assumption was that paleontology as an evidence-based and knowledge-generating practice was at odds with capitalist interests.

On the other hand, fossil dealers argued that these hostile feelings towards a market economy was a result of misunderstanding. In direct response to the former statement made by and on behalf of academic paleontologists, Larson and colleague Donna Russell spoke for the commercial fossil industry. "We believe, on the other hand, that the demonization and marginalization of a specific portion of the paleontological community is the result of misunderstanding, misplaced entitlement and simple intolerance," wrote Larson and Russell. "Such attitudes endanger the future of the very science of paleontology and paleontological collections on which it is based" (Larson and Russell 2014). The heart of their counterargument drew on the assumption that science and commerce were naturally compatible entities. ${ }^{23}$

Crucially, this is not a trivial argument over money, or a mere fight for prestige. Indeed, some paleontologists believe commercial fossil collection threatens their scientific authority, autonomy, and identity. Thus, some have crafted arguments or counter-arguments in an effort to demarcate their work from that of commercial collectors, amateurs, or others in the community. Thomas Gieryn referred to this as "boundary-work" (Gieryn 1983, 1999). For Gieryn, boundary-work is a process by which scientists construct, deconstruct, and negotiate definitions of what (in their view) gets to count as science. But as he argued, there is no one way to do science. Rather, there are different ways of drawing or redrawing the boundaries that bolster a certain view of science. "Boundary-work becomes a means of social control," explained Gieryn. "As the borders get placed and policed, 'scientists' learn where they may not roam without transgressing the boundaries of legitimacy, and 'science' displays its ability to maintain monopoly over preferred norms of conduct" (Gieryn 1999, 16). In particular, scientists build boundaries when they feel their authority is at stake. In many cases, scientists are seeking to defend their interests by demarcating their work from other interests they consider to be non-scientific at best or detrimental to science at worst. Although a natural response, the effects are far from neutral.

Paleontologist Eric Scott voiced his concern of a growing popular misperception that academics and fossil dealers were one in the same precisely because it encouraged a "widespread misperception of how paleontology works" (Scott 2005). As far as he was concerned, this "misperception" is "understandable" but "wrong" and has severe consequences for the field's credibility. "In the majority of cases," explained Scott, "commercial fossil collecting is not paleontology. It is not science. Those points of overlap between actual paleontology and commercial fossil

\footnotetext{
${ }^{23}$ In 2016, the European Association of Vertebrate Palaeontologists (EAVP) hosted a symposium to address the ethical collecting, buying, and selling of fossil vertebrate specimens. The overall message of the meeting was to point out how fossil ethics is not a black-and-white issue. Jeff Liston, paleontologist and symposium organizer, wrote, "Pretending that the issues are one-way is not only simplistic, it is detrimental" (Liston 2016, 27).
} 
hunting - fieldwork, lab work, and restoration - are the beginnings of the scientific process, representing the data-acquisition stage of an investigation. But they do not constitute a complete scientific program" (Scott 2005).

With a bold claim like this, Scott drew more than one boundary around paleontology. First, he claimed that the selling of fossils was distinctly different from the study of fossils in that the former is not science. According to Scott, some fossil dealers assumed the appearance of a paleontologist, but their motivations were primarily monetary and their research, if any, was likely unreliable. He also argued that commercial fossil collection was not neutral in its effects on the field of paleontology. Not only was it not science, but it was bad for science. From his view, the mere existence of commercial fossil collection impended on the integrity of fossil research and the paleontologist's scientific authority as a credible knowledge producer. Here, the assumption was that science and commerce were at grave odds, thus boundarywork served to draw a line between the two.

In its most extreme form, this characterization presents fossil dealers as borderline deceptive or even outright fraudulent. Historically speaking, fraudulent beahvior in paleontology was nothing new. As Rieppel demonstrated, paleontology's history is full of stories about hoaxes and great fakes as some people gave in to the temptation to tamper with specimens in order to make them appear grander or rarer than they were, thus more desirable and more expensive. Such hoaxes challenged paleontology's credibility. Evidence of fradulent beahvior, or even the slightest accusations of it, Rieppel argued, served to exclude certain people from the scientific community in an attempt to protect the community's authority (Rieppel 2018). Thus, accusations of bad science or pseudoscience were not to be taken lightly.

As some tried to argue commercial collectors out of the community, fossil dealers have been quick to draw on the field's past to justify their trade. Triebold, for instance, endorsed commercial paleontology's historical and scientific significance, arguing that commercial contributions to the field were vast in number and impressive in quality. "Commercial fossil trading in the United States started with quarrymen in New Jersey selling fossils to Joseph Leidy during the mid-1800 s," he wrote. "By the $1870 \mathrm{~s}$, professional collectors were busy filling museums with dinosaurs and other fossils, by accepting the risks of exploration, discovery and excavation, then selling their discoveries, and in some cases collecting fossils on a contract basis," explained Triebold. "Visit any number of prestigious institutions and you will see magnificent displays whose very existence is owed to professional collectors" (Triebold 2007, 136). Not only were fossil dealers valuable (even essential) participants in building up paleontological collections, but others argued that their existence was primarily responsible for the birth of the field. "Animosity directed toward commercial collecting is relatively new, but the sale of fossils is not," argued Near Larson and colleagues. "Commercial collecting predates the relatively young science of paleontology and has been intertwined in modern paleontology since at least the late 1700's with Mary Anning [...]" (Larson et al. 2017, 2). Here, both arguments were made in efforts to legitimize commercial fossil collection as a valid practice within the paleontological community.

In the history of paleontology, Mary Anning is a foundational figure in the birth of the field. She was one of the first and most prolific fossil hunters, making great 
finds along the Jurassic coast fossil beds in the Southwest of England, and providing early descriptions of ancient marine creatures (Emling 2011). She was also one of the earliest examples of the interplay between science and commerce, particularly as evidence for how the scientific and economic value of fossils could coexist. Anning, among other early fossil hunters, sold fossils in exchange for cash. However, profit was not her sole motive. She was also in the business for the credit. Rieppel explained it best in terms of a mixed economy where Anning engaged in such transactions for the moral and market value, for credit or prestige among naturalists and for its financial benefits as a source of livelihood. Similarly, Anne Secord offered another example of a mixed economy of transactions, this time among nineteenth-century "artisan" botanists and entomologists with British gentlemen naturalists. These artisan and gentlemen naturalists were not of the same social status so engaged with each other via letters of correspondence and for reasons other than social overlap or financial incentive. Rather, artisan naturalists were motivated to correspond with gentlemen naturalists of a higher social ranking by gifting specimens or sharing information at no cost and sometimes also for no credit. They valued the interaction because it spoke to their significance and acceptance within the natural history community (Secord 1994, 2002). Indeed, something similar can be said of the paleontology community today as some people seek to merge the financial exchange of fossils with the intellectual contribution to knowledge. Some, particularly commercial collectors, assume this perspective of a mixed economy in which market and moral values coincide to be unproblematic. Meanwhile, some others take a very different view. Moving forward, this concept of a mixed economy of transactions might very well help us to untangle assumptions of the compatibility (or incompatibly) of science and commerce, and to better understand what is really at stake for those involved in this broader debate over fossil access.

\section{Conclusion}

In reporting for The New York Times, Malcolm Browne remarked on Sue's multimillion-dollar price tag and the fact that the Field Museum of Natural History was able to afford it thanks to Disney's and McDonald's financial support. "Many scientists expressed relief that the valuable fossil would remain in the United States in an educational institution," wrote Browne. "But the winning bid-which was underwritten by financing from several corporations-underscored how commerce had intruded into a world once left to scientists" (Browne 1997). In one sense, Browne was right. In another sense, he was very wrong.

Most paleontologists, especially members of SVP, were relieved with the way Sue's story ended. As one of the most scientifically important and financially valuable fossil specimens ever discovered, scientists relaxed knowing Sue would be expertly prepared by qualified researchers at a world-renowned research museum like the Field Museum. Browne, however, was wrong in thinking that Disney's and McDonald's joint-venture in financing Sue's purchase was anything unusual. To be clear, Sue's story is fascinating and unique for its own reasons. It offers a view into the state of late twentieth-century science revealing its very intimate and 
very outward facing relationship with the broader political, cultural, and economic landscape. But as historians of science have demonstrated, and this article has discussed, collaborations between scientific institutions and the corporate powerhouses of their time was hardly new. Rieppel showcased how business giants and political tycoons from Rockefeller to Carnegie partnered with early twentieth-century paleontologists to finance science in exchange for social influence and public approval. In the process, they tried to maintain a credible reputation within a moral and market economy.

Since then, scientists and fossil dealers alike have tried to navigate the values of these two worlds (including the overlap between them). Some have done this successfully, while others have not. Sue's story is an exceptional example of the latter. Over the course of a decade, various stakeholders from academic paleontologists and commercial collectors to Native Americans, private citizens, and government officials engaged in very public debates in search for an answer to "Who owns Sue?" Both individuals and groups staked claim to Sue but justified those claims through different arguments based on different values and assumptions of authority. Larson and the BHI, for example, assumed authority over Sue in terms of ownership and expertise. The United States Department of Justice and Department of Interior, along with the Cheyenne River Sioux Tribe, assumed ownership of Sue for legal reasons. Scientists, particularly members of SVP, assumed authority over Sue on the basis of the specimen's research value, their own scientific expertise, and the need for public accessibility. Further, regulatory and legislative attempts to control fossil access on government property both before and after Sue's discovery were laden with assumptions of authority regarding the proper relationship between science and capitalism.

This article has argued that assumptions of authority were responsible for initiating and sustaining debates over fossil access in the case of Sue. From this view, I have offered a more robust characterization of the various stakeholders' motivations for pursuing Sue. In doing so, I have highlighted how assumptions of authority both informed and reinforced the boundaries they embraced in response to a highly public scientific controversy. The concept of boundary objects, namely our understanding of Sue as an example of one, widens our view of the situation, allowing us to see the numerous people and understand the various values they bestowed upon this fossil. Likewise, the process of boundary-work-by which individuals and groups police their domain to protect their authority, autonomy, and legitimacy-tells us much more about the innerworkings of science in a market economy. Appreciation of the "how" and "why" behind stakeholders' decisions to create literal and figurative boundaries around Sue can serve as a framework for investigating the broader debate over fossil access.

Open Access This article is distributed under the terms of the Creative Commons Attribution 4.0 International License (http://creativecommons.org/licenses/by/4.0/), which permits unrestricted use, distribution, and reproduction in any medium, provided you give appropriate credit to the original author(s) and the source, provide a link to the Creative Commons license, and indicate if changes were made. 


\section{References}

Assessment of Fossil Management on Federal \& Indian Lands. (2000). Report of the Secretary of the Interior, $1-50$.

Barrow, M. (1998). A passion for birds: American ornithology after Audubon. Princeton: Princeton University Press.

Barrow, M. (2000). The specimen dealer: Entrepreneurial natural history in America's Gilded age. Journal of the History of Biology, 33(3), 493-534.

Brinkman, P. D. (2010). The second Jurassic dinosaur rush: Museums and paleontology in America at the turn of the twentieth century. Chicago: University of Chicago Press.

Browne, M. W. (1992). F.B.I. Seizes tyrannosaur in fight on fossil custody. The New York Times. https:// www.nytimes.com/1992/05/19/us/fbi-seizes-tyrannosaur-in-fight-on-fossil-custody.html.

Browne, M. W. (1996). Fossil dealer, target of federal prosecutors, Begins jail term. The New York Times, February 22, 1996.

Browne, M. W. (1997). Tyrannosaur skeleton is sold to a museum for $\$ 8.36$ million. The New York Times. http://www.nytimes.com/1997/10/05/nyregion/tyrannosaur-skeleton-is-sold-to-a-museum-for-8.36million.html.

Collins, H. (2004). Gravity's shadow: The search for gravitational waves. Chicago: Univeristy of Chicago Press.

Collins, H. (2010). Gravity's ghost: Scientific discovery in the twenty-first century. Chicago: University of Chicago Press.

Collins, H., Evans, R., \& Gorman, M. (2007). Trading zones and interactional expertise. Studies in History and Philosophy of Science Part A, 38, 657-666. https://doi.org/10.1016/j.shpsa.2007.09.003.

Dalton, R. (2001). US lays out bare bones of fossil protection package. Nature, 413(6856), 555. https:// doi.org/10.1038/35098213.

Duffy, P., \& Lofgren, L. (1994). Jurassic farce: A critical analysis of the government's seizure of 'Sue', a sixty-five-million-year-old Tyrannosaurus rex fossil. South Dakota Law Review from the School of Law at University of South Dakota, 39(3), 478.

Emling, S. (2011). The fossil hunter: Dinosaurs, evolution, and the woman whose discoveries changed the world. London: Palgrave Macmillan.

Fiffer, S. (2000). Tyrannosaurus Sue: The extraordinary saga of the largest, most fought over T. Rex ever found. New York: W. H. Freeman and Company.

Fossils Protected in US Land Legislation. (2009). Nature, 458, 562. https://doi.org/10.1038/458562e.

Fourcade, M. (2011). Cents and sensibility: Economic valuation and the nature of 'nature'. American Journal of Sociology, 116(6), 1721-1777.

Gieryn, T. F. (1983). Boundary-work and the demarcation of science from non-science: Strains and interests in professional ideologies of scientists. American Sociological Review, 48(6), 781-795.

Gieryn, T. F. (1999). Cultural boundaries of science: Credibility on the line. Chicago: Univeristy of Chicago Press.

Hilgartner, S. (2017). Reordering life: Knowledge and control in the genomics revolution. Cambridge: The MIT Press.

Jaffe, M. (2001). The gilded dinosaur: The fossil war between E.D. Cope and O.C. Marsh and the rise of American science. Victoria: Crown Publications.

Keeney, E. B. (1992). The botanizers: Amateur scientists in nineteenth-century America. Chapel Hill: University of North Carolina Press.

Lane, N. G. (1989). Paleontology: The academy and the marketplace. Journal of Paleontology, 63(3), $259-260$.

Larson, N. L., Stein, W. Triebold, M. \& Winters, G. (2017). What commercial fossil dealers contribute to the science of paleontology. The Journal of Paleontological Sciences, (11). http://www.aaps-journ al.org/pdf/contibutions-to-paleontology.pdf.

Larson, P., \& Donnan, K. (2002). Rex appeal: The amazing story of Sue, the dinosaur that changed science, the law, and my life. Montpelier: Invisible Cities Press.

Larson, P., \& Russell, D. (2014). The benefits of commercial fossil sales to 21 st-century paleontology. Palaeontologia Electronica, 17(1), 1-7.

Lavine, G. (2005). Fossil thief put officials between a rock and a hard place. The Salt Lake Tribune. May 5, 2005. https://archive.sltrib.com/story.php?ref=/utah/ci_2709375. 
Liston, J. (2016). 'Fossillegal': A symposium on ethics in palaeontology. European Association of Vertebrate Palaeontologists Newsletter, 93, 27-30.

Lucier, P. (2009). The professional and the scientist in nineteenth-century America. Isis, 100(4), 699-732.

Malmsheimer, R. W., \& Hilfinger, A. S. H. (2003). In search of a paleontological resources policy for federal lands. Natural Resources Journal, 43, 587-614.

Miller, T. D. (2014). Dinosaur 13. Documentary. Directed by Todd Douglas Miller.

Mitchell, W. J. T. (1998). The last dinosaur book: The life and times of a cultural icon. Chicago: Univeristy of Chicago Press.

Morell, V. (1992). Dustup in the bone pile: Academics v. collectors. Science 258 (5081): 391-92. http:// www.jstor.org.libproxy.ucl.ac.uk/stable/pdf/2879965.pdf?refreqid=excelsior\%3A0ca9a654f42cf $135378 \mathrm{e} 76 \mathrm{ef} 1 \mathrm{fe} 11518$.

Nieuwland, I. (2019). American dinosaur abroad: A cultural history of Carnegie's plaster Diplodocus. Pittsburgh: University of Pittsburgh Press.

Paleontological Resource Preservation Act. (2009) Society for Vertebrate Paleontology. Retrieved October 22, 2018. http://vertpaleo.org/The-Society/Advocacy/Paleontological-Resources-PreservationAct.aspx.

Pringle, H. (2014). Selling America's Fossil Record. Science, 343(6169), 364-367. https://doi. org/10.1126/science.343.6169.364.

Pringle, H. (2013). Not sold! 'Dueling Dinos' flop at auction. Science, November 19, 2013. http://www. sciencemag.org/news/2013/11/not-sold-dueling-dinos-flop-auction.

Rainger, R. (1991). An agenda for antiquity: Henry Fairfield Osborn and vertebrate paleontology at the American Museum of Natural History, 1890-1935. Tuscaloosa: The University of Alabama Press.

Raup, D., Black, C., Blakstone, S., Dole, H., Grogan, S., Larson, P., et al. (1987). Paleontological collecting. Washington, D. C.: National Academy Press.

Rea, T. (2004). Bone wars: The excavation and celebrity of Andrew Carnegie's dinosaur. Pittsburgh: University of Pittsburgh Press.

Reingold, N. (1979). Definitions and speculations: The professionalization of science in America in the nineteenth century. In A. Oleson \& J. Voss (Eds.), The organization of knowledge in modern America in the Nineteenth Century, 1860-1920. Baltimore: Johns Hopkins University Press.

Rieppel, L. (2012). Bringing dinosaurs back to life exhibiting prehistory at the American Museum of Natural History. Isis, 103, 460-490.

Rieppel, L. (2015). Prospecting for dinosaurs on the mining frontier: The value of information in America's Gilded Age. Social Studies of Science, 45(2), 161-186.

Rieppel, L. (2018). Hoaxes, humbugs, and frauds: Distinguishing truth from untruth in early America. Journal of the Early Republic, 38(3), 501-529.

Rieppel, L. (2019). Assembling the dinosaur: Fossil hunters, tycoons, and the making of a spectacle. Cambridge, Massachusetts: Harvard University Press.

Scott, E. (2005). Is selling vertebrate fossils bad for science? PALAIOS, 20(6), 515-517.

Secord, A. (1994). Corresponding interests: Artisans and gentlemen in nineteenth-century natural history. The British Journal for the History of Science, 27(4), 383-408.

Secord, A. (2002). Artisan naturalists: Science as popular culture in nineteenth century England. London: University of London.

Shimada, K., Currie, P. Scott, E. \& Sumida, S. (2014). The greatest challenge to 21st century paleontology: When commercialization of fossils threatens the science. Palaeontologia Electronica, 17(1), $1-4$.

Smocovitis, V. B. (1996). Unifying biology: The evolutionary synthesis and evolutionary biology. New Haven: Princeton University Press.

Star, S. L., \& Griesemer, J. R. (1989). Institutional ecology, 'translations' and boundary objects: Amateurs and professionals in Berkeley's Museum of Vertebrate Zoology, 1907-39. Social Studies of Science, 19(3), 387-420.

Switek, B. (2009). Tussling over 'Tinker' the Tyrannosaurus. Smithsonian Magazine, August 11, 2009. https://www.smithsonianmag.com/science-nature/tussling-over-tinker-the-tyrannosaurus-50530 $023 /$.

Triebold, M. (2007). Fossils: New journal will oppose illegal trade. Nature, 446(7132), 136-136. https:// doi.org/10.1038/446136c.

Webster, D. (2009). The dinosaur fossil wars. Smithsonian Magazine. April 2009. https://www.smith sonianmag.com/science-nature/the-dinosaur-fossil-wars-116496039/. 
Publisher's Note Springer Nature remains neutral with regard to jurisdictional claims in published maps and institutional affiliations. 